\title{
Status disclosure for adolescents with HIV
}

\author{
Annisah Annisah ${ }^{1 *}$, Johanna Debora Imelda ${ }^{2}$, and Mona Sugianto ${ }^{3}$ \\ ${ }^{1}$ Social Welfare Department, Faculty of Social and Political Science, Universitas Indonesia, Depok, \\ Indonesia \\ ${ }^{2}$ Social Welfare Department, Faculty of Social and Political Science, Universitas Indonesia, Depok, \\ Indonesia \\ ${ }^{3}$ Faculty of Psychology, Universitas Katolik Atmajaya, Jakarta, Indonesia
}

\begin{abstract}
The number of Adolescents with HIV in Indonesia in these last 4 years continuously increases. This condition brings new prospect that children who are born with HIV have better life expectancy with its following complexities. One of the biggest challenges is the issue of disclosure status. This study employs action research approach to reveal better alternative patterns of disclosure for revealing HIV status of adolescents. The results of the study show that the disclosure status will be successful if the adolescents and primary caregivers have a high level of readiness both on cognitive, affective, psychomotor, existential-spiritual, and social aspects. When the combination of these is not less than 8 , the disclosure process can be predicted to succeed. If it is less than that, it would be better off to prepare all those eight aspects. Authors argue disclosure status is not only determined by who does that, rather adolescents and caregiver must be parallel prepared and ready to disclose. Therefore, it is important to assess readiness before the disclosure status process is carried out.
\end{abstract}

\section{Introduction}

\subsection{Background}

Increasing cases of HIV / AIDS occur not only to people with high risk (such as drug users, homosexuals, commercial sex workers) but also have developed into non-high-risk groups such as productive women and housewives. In fact, the number of cases of transmission from mother to child continues to increase. HIV transmission in infants and children can occur horizontally through blood transfusion, or vertically from mother to baby born during pregnancy, childbirth, and lactation or breastfeeding from mothers with HIV. This condition results many children born with HIV. In these last four years, the number of adolescents and children with HIV continues to increase.

Although many claim that children born with HIV risk have a low life expectancy, however, the fact tells many have been able to survive up to their adolescents stage. This condition is indicated because of the positive contribution of antiretroviral therapy (ART).

\footnotetext{
${ }^{*}$ Corresponding author: annisah88@ui.ac.id
} 
This condition sheds a light of hope as well as enormous challenge. The psycho-social problems faced by children from families exposed to HIV/AIDS will meet various problems. Previous research shows family members with HIV have negative effect to their family as a whole [1]. This condition gets worse for children from such family. Children in such family potentially become orphan, lose one or both parents who pass away because of AIDS, deteriorating financial conditions, live in a risky environment since their parents living with chronic diseases due to opportunistic infections [2]. These conditions cause children with HIV to be significantly vulnerable.

Not only the quality of life of children with HIV is significantly concerning. Previous studies have shown increasing life expectancy is not necessarily followed by increasing quality of life of children with HIV. These various opportunistic infectious diseases gradually cause their health conditions deteriorating. Preliminary findings from interviews with a pediatrician at Cipto Mangunkusumo Hospital (RSCM) who treats children with HIV/AIDS found that there are several psycho-social problems affecting the quality of life of children with HIV. First, because there is general agreement in Indonesia not to disclose the child's HIV status until they are 15 years old, almost all children do not know their own HIV status (disclosure). Second, their quality of life is no different from children from the same social environment. In the group of 10-14 years, it shows no difference with children who are not infected with HIV. However, in the situation of children who already know their status, their status is kept as a family secret so that their presence in the community is not stigmatized as an HIV family. Third, there are many RSCM patients who are lost to follow-up, especially when it comes to broken family. However, RSCM has prepared a safety net, by entrusting children who are discarded by families to families of people living with HIV/AIDS who are willing to accommodate. Unfortunately, only a few families are willing to do it (In-depth Interview with a pediatrician who treats ADHA).

The low life quality of adolescents with HIV is related to the level of ARVs consumption. Compliance with consumption of ARVs has become more challenging in their adolescent [3]. At this stage, they are increasingly critical, exposed with information, and interact with community [4]. Based on information from one of the adolescent with HIV, their biggest challenge is incompliance to ARV consumption. This happens because they do not know what they consume and what the benefits are. The results of the research conducted previously showed that most caregivers did not dare to disclose their status because children were considered not sufficiently understand what HIV is and worried that it would adversely affect the quality of health, stigmatization, and discrimination from others. On the other hand, children will ask them why caregiver gives the drug continuously and when it will end. To answer these questions, many of the caregivers lied to teenagers by giving false information such as heart disease and other chronic illnesses. Even, there was a case when a child with HIV was informed ARV as vitamins for beauty and aesthetics and she distributed ARVs to friends at school. This condition shows that by not disclosing their status to the children does not only bring negative effect to the children but also their surroundings. Meanwhile, the results of other studies show that the number of children who already know their status is still very small and many know this status because of accidental event. As a result, they increasingly resist and disobey the consumption of ARVs.

Meanwhile, a study conducted by WHO stated status disclosure to children had a positive impact on the quality of children's health, because children were more obedient with the consumption of ARVs [5]. Meanwhile, negative impacts on the psychological aspects that arise due to disclosure do not exist. Hence, efforts to status disclosure become a crucial issue that must be overcome immediately. By opening status, it does not only fulfill the basic rights of youth but also as an effort to improve their life quality. Thus, their accessibility to education becomes more open and in the long run will contribute positively to Indonesia's 
development. However, efforts to disclose status are still an enormous challenge, given status disclosure in Indonesia is still considered a taboo - including among professionals.

This paper aims to describe patterns of readiness before status disclosure is conducted. To explain, authors develop a disclosing status model by using a framework which combines five aspects: cognitive, affective, psychomotoric, spiritual-existential, and social. Ideally, all these aspects must be owned by both teenagers and primary caregivers.

Table 1. The framework readiness of disclosing status.

\begin{tabular}{|c|c|c|c|c|c|c|}
\hline \multirow[t]{2}{*}{ No } & \multirow[t]{2}{*}{$\begin{array}{l}\text { Readiness } \\
\text { Aspect }\end{array}$} & \multirow[t]{2}{*}{ Indicators } & \multicolumn{2}{|c|}{ Caregiver } & \multicolumn{2}{|c|}{$\begin{array}{l}\text { Adolescent with } \\
\text { HIV }\end{array}$} \\
\hline & & & $\mathrm{R}$ & U & $\mathrm{R}$ & $\mathrm{U}$ \\
\hline \multirow[t]{5}{*}{1} & \multirow[t]{5}{*}{ Cognitive } & 1. IQ (if any) & & & & \\
\hline & & 2. Language Ability & & & & \\
\hline & & 3. Basic knowledge about HIV & & & & \\
\hline & & 4. Ability to think abstractly & & & & \\
\hline & & 5. Self-Conception & & & & \\
\hline \multirow[t]{5}{*}{2} & \multirow[t]{5}{*}{ Affective } & 1. Personality Evaluation & & & & \\
\hline & & 2. Dominant Emotion & & & & \\
\hline & & 3. Emotional Management & & & & \\
\hline & & 4. $\quad$ Stress Tolerance & & & & \\
\hline & & 5. Life-Value & & & & \\
\hline \multirow[t]{7}{*}{3} & \multirow[t]{7}{*}{ Psychomotoric } & 1. Problem Solving Ability & & & & \\
\hline & & 2. Communication Ability & & & & \\
\hline & & 3. Habit & & & & \\
\hline & & 4. Lifestyle - Dietary Habit & & & & \\
\hline & & 5. Lifestyle - Sleep Habit & & & & \\
\hline & & 6. Lifestyle - Activity Habit & & & & \\
\hline & & 7. Lifestyle - Exercise Habit & & & & \\
\hline \multirow[t]{7}{*}{4} & \multirow[t]{7}{*}{$\begin{array}{l}\text { Spiritual- } \\
\text { existential }\end{array}$} & $\begin{array}{l}\text { 1. Ability to identify life } \\
\text { objective }\end{array}$ & & & & \\
\hline & & 2. Ability to value life & & & & \\
\hline & & 3. Ability to give life meaning & & & & \\
\hline & & 4. $\quad$ Spiritual Understanding & & & & \\
\hline & & $\begin{array}{l}\text { 5. The belief that life is not only } \\
\text { for now, but for a more distant } \\
\text { and meaningful journey }\end{array}$ & & & & \\
\hline & & $\begin{array}{l}\text { 6. Belief to entrust life's } \\
\text { suffering to something more } \\
\text { Supreme/God. }\end{array}$ & & & & \\
\hline & & $\begin{array}{l}\text { 7. Ability to understand life } \\
\text { principle }\end{array}$ & & & & \\
\hline \multirow[t]{2}{*}{5} & \multirow[t]{2}{*}{ Social } & $\begin{array}{l}\text { 1. Relationships in the family } \\
\text { where the caregiver and } \\
\text { positive teenagers live }\end{array}$ & & & & \\
\hline & & $\begin{array}{l}\text { 2. Relations with the } \\
\text { surrounding environment }\end{array}$ & & & & \\
\hline
\end{tabular}




\begin{tabular}{|l|l|l|l|l|l|l|}
\hline & 3. & $\begin{array}{l}\text { Relations at the school / } \\
\text { workplace / organization }\end{array}$ & & & & \\
\hline & \begin{tabular}{l} 
4. $\begin{array}{l}\text { Involvement in Support } \\
\text { Groups }\end{array}$ \\
\cline { 3 - 6 }
\end{tabular} & & & & \\
\hline & & & & \\
\hline
\end{tabular}

$\mathrm{R}=$ Ready

$\mathrm{U}=$ Unready

\section{Methodology research}

This article is one of the results of a more comprehensive study discussing the life of children with HIV and its caregivers. The study used a participatory action research approach, a research approach commonly used to look for intervention models through a pilot project. Based on the principle of action research proposed by [7], this research was conducted in accordance with the stages consisting of look, think and act, as in the following table:

Table 2. Research action basic stages.

\begin{tabular}{|l|cl|}
\hline Stages & Activities \\
\hline Look & $\bullet$ & Collecting data through interviews and group discussions \\
& $\bullet$ & Defining and Describing Data \\
\hline Think & $\bullet$ & Exploring and Analyzing Data \\
& $\bullet$ & Interpreting and Explaning Data conducted by research team with related \\
& & NGO and psychologist. \\
\hline Act & - $\begin{array}{l}\text { Planning. At this stage, researchers and related stakeholders try to } \\
\text { develop several alternative programs that will be conducted. }\end{array}$ \\
& - Implementation \\
\hline
\end{tabular}

The method of data collection applies a qualitative approach that is not only used in the look phase but involved at each stage of action research. Neuman also mentions qualitative research as an interpretive social science which means the research process carried out emphasizes the meaning of each data obtained [6]. In relation to action research, this process of meaning can be done at the analysis stage (think). In the act stage, this research will focus on the implementation process developed based on the results of the research at the look and think stage. The stages consist of planning, implementation, and evaluation. Planning is important to re-prioritize the most important activities carried out in this action research process. Every process at the act stage strongly emphasizes the participation of the research participants [7].

Data collection is carried out in several stages, as follows: literature study and observation; secondary data collection; deep interview; focus group discussion. Primary data collection was carried out on 19 children who were known to be positive and had just started taking ARVs at the age of 5 years. They include children with HIV who have survived as well. Nineteen children with HIV were included together with supporting respondents, namely primary parents/caregivers, assistants from NGOs, and pediatricians who took care of them. The total number of respondents involved in this study were 45 people. All respondents reside in the Jakarta-Bogor-Depok-Tangerang-Bekasi area. Meanwhile, for the pilot project a disclosure status intervention model was conducted on $10 \mathrm{key}$ respondents and their main caregivers. Data collection and situation analysis were conducted from 2015 to 2016. This stage is in the stage of action research, Stringer calls it the look and think stage. 
The act stage was done with detailed program planning. One program that is considered as a priority was disclosure status carried out in 2017.

\section{Result and discussion}

The disclosure program status was taken place in two major stages, namely caregiver education and mentoring disclosure process. Caregiver education was conducted to improve the knowledge of the primary caregiver of children related to HIV / AIDS, disclosure status, and effective communication. In the session regarding disclosure status, five aspects of readiness are explained in detail before disclosure is carried out. The second stage was the mentoring process. At this stage, a framework for preparing disclosure status had been implemented previously. These five aspects were then used as the basis for determining the extent of the child's readiness and also the caregiver to do the disclosure process. The important point is that the status disclosure process must be conducted by the main caregiver. Caregiver is the closest person to have more inner bond with teenagers.

The mentoring process was carried out three times. The first assistance was conducted to assess the readiness of children and caregivers. The second facilitation was for the preparation of the disclosure strategy, and the last assistance was disclosure status. In practice, this stage is very flexible, adapting to the condition of adolescents and caregivers.

In the framework of readiness for disclosure status (see table 1) it is used to measure the extent of the readiness of adolescents and caregivers to conduct disclosure. To find out, it is done in an in-depth interview and observation. For the social aspect, the efforts made were observation in a long period of time (at least one hour) so that conditions can be measured for the readiness of positive caregivers and adolescents. Interviews and observations were needed to listen to "what is said" and "what is not said" by caregivers and positive teenagers. Therefore, 'trusts' from caregivers and positive adolescents were the starting point for this assessment. Each indicator was checked in the column ready and Unready and then added up. These results were then analysed to determine the degree of readiness. This was carried out in all aspects, both for teenagers and caregivers.

Of the 10 respondents, there are only four people who managed to do disclosure status, either full or partial. Meanwhile, there were two respondents who only found out that their children knew their status before this process was carried out. His aunt as the main caregiver only found out that teenager $\mathrm{C}$ knew his status when $\mathrm{C}$ was fighting with his uncle. $\mathrm{C}$ has been known to be disobedient in consuming ARVs and is now in line 2 . This finding is in line with previous research that when children know that their status is Unready, they will have a negative impact on overall quality of life.

Meanwhile, three other respondents still did not succeed in completing disclosure status because they were still Unready, both for adolescents and caregivers. Data shows that respondents who did not succeed in disclosing status, having total readiness value of $\leq 7$ points.

Table 3. Data of respondent readiness levels.

\begin{tabular}{|c|c|c|c|c|c|c|c|c|}
\hline \multirow[b]{2}{*}{ No } & \multirow[b]{2}{*}{ Category } & \multicolumn{5}{|c|}{ Aspect } & \multirow[b]{2}{*}{$\begin{array}{c}\text { Total } \\
\text { Readin } \\
\text { ess }\end{array}$} & \multirow[b]{2}{*}{$\begin{array}{l}\text { Informa } \\
\text { tion }\end{array}$} \\
\hline & & $\begin{array}{l}\text { Cogniti } \\
\text { ve }\end{array}$ & $\begin{array}{l}\text { Affecti } \\
\text { ve }\end{array}$ & $\begin{array}{l}\text { Psycho } \\
\text { motoric }\end{array}$ & $\begin{array}{l}\text { Existen } \\
\text { tial - } \\
\text { Spiritua } \\
1\end{array}$ & Social & & \\
\hline \multirow{2}{*}{$\begin{array}{c}\text { Model } \\
1\end{array}$} & Adolescent & $\mathrm{R}$ & $\mathrm{R}$ & $\mathrm{R}$ & $\mathrm{R}$ & $\mathrm{R}$ & \multirow[b]{2}{*}{10} & \multirow{2}{*}{$\begin{array}{l}\text { Succeed } \\
\text { full- } \\
\text { disclose }\end{array}$} \\
\hline & Caregiver & $\mathrm{R}$ & $\mathrm{R}$ & $\mathrm{R}$ & $\mathrm{R}$ & $\mathrm{R}$ & & \\
\hline & Adolescent & $\mathrm{U}$ & $\mathrm{R}$ & $\mathrm{R}$ & $\mathrm{U}$ & $\mathrm{R}$ & 8 & \\
\hline
\end{tabular}




\begin{tabular}{|c|c|c|c|c|c|c|c|c|}
\hline $\begin{array}{c}\text { Model } \\
2\end{array}$ & Caregiver & $\mathrm{R}$ & $\mathrm{R}$ & $\mathrm{R}$ & $\mathrm{R}$ & $\mathrm{R}$ & & $\begin{array}{l}\text { Succeed } \\
\text { full- } \\
\text { disclose }\end{array}$ \\
\hline \multirow{2}{*}{$\begin{array}{c}\text { Model } \\
3\end{array}$} & Adolescent & $\mathrm{U}$ & $\mathrm{R}$ & $\mathrm{R}$ & $\mathrm{U}$ & $\mathrm{R}$ & \multirow[t]{2}{*}{8} & \multirow{2}{*}{$\begin{array}{l}\text { Succeed } \\
\text { partial } \\
\text { disclose }\end{array}$} \\
\hline & Caregiver & $\mathrm{R}$ & $\mathrm{R}$ & $\mathrm{R}$ & $\mathrm{R}$ & $\mathrm{R}$ & & \\
\hline \multirow{2}{*}{$\begin{array}{c}\text { Model } \\
4 \\
\end{array}$} & Adolescent & $\mathrm{U}$ & U & $\mathrm{U}$ & U & $\mathrm{R}$ & \multirow[t]{2}{*}{6} & \multirow{2}{*}{ Failed } \\
\hline & Caregiver & $\mathrm{R}$ & $\mathrm{R}$ & $\mathrm{R}$ & $\mathrm{R}$ & $\mathrm{R}$ & & \\
\hline \multirow{2}{*}{$\begin{array}{c}\text { Model } \\
5\end{array}$} & Adolescent & $\mathrm{U}$ & $\mathrm{U}$ & $\mathrm{U}$ & $\mathrm{U}$ & $\mathrm{R}$ & \multirow[b]{2}{*}{3} & \multirow{2}{*}{$\begin{array}{l}\text { Failed } \\
\text { disclose }\end{array}$} \\
\hline & Caregiver & $\mathrm{U}$ & $\mathrm{U}$ & $\mathrm{R}$ & $\mathrm{U}$ & $\mathrm{R}$ & & \\
\hline \multirow{2}{*}{$\begin{array}{c}\text { Model } \\
6 \\
\end{array}$} & Adolescent & $\mathrm{U}$ & $\mathrm{R}$ & $\mathrm{U}$ & $\mathrm{U}$ & $\mathrm{R}$ & \multirow[b]{2}{*}{6} & \multirow{2}{*}{$\begin{array}{l}\text { Failed } \\
\text { disclose }\end{array}$} \\
\hline & Caregiver & $\mathrm{R}$ & $\mathrm{R}$ & $\mathrm{R}$ & $\mathrm{U}$ & $\mathrm{R}$ & & \\
\hline \multirow{2}{*}{$\begin{array}{c}\text { Model } \\
7\end{array}$} & Adolescent & $\mathrm{R}$ & U & $\mathrm{R}$ & $\mathrm{U}$ & $\mathrm{U}$ & \multirow{2}{*}{7} & \multirow{2}{*}{$\begin{array}{l}\text { Failed } \\
\text { disclose }\end{array}$} \\
\hline & Caregiver & $\mathrm{R}$ & $\mathrm{R}$ & $\mathrm{R}$ & $\mathrm{R}$ & $\mathrm{R}$ & & \\
\hline
\end{tabular}

$\mathrm{R}=$ Ready

$\mathrm{U}=$ Unready

From the description of the table above it is evident that there are several similar models. In models 1-3 show a successful pattern. This pattern delineates the sum of the level of readiness of caregivers and adolescents at level 8. Oppositely, a combination of less than 8 displays a pattern that is not successful in disclosure status. This finding indicates that the level of readiness of adolescents and caregivers before disclosure status is a minimum of 8 . Under that number, it is considered difficult to conduct. And if it is forced, it potentially will cause a negative response for adolescents.
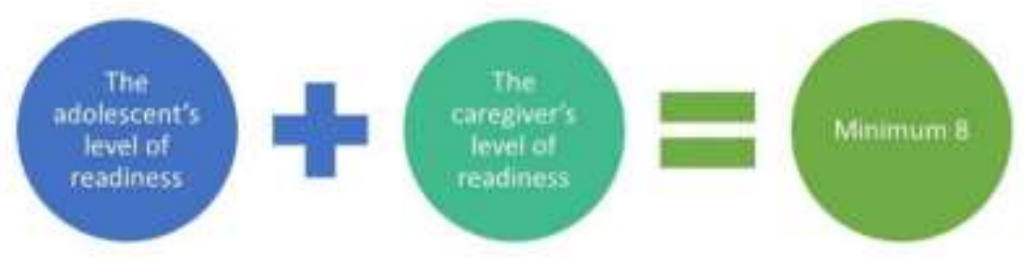

Figure 1: Diagram proses disclosure status

Point 8 is the result of a combination of the level of readiness of adolescents and caregivers. The level of readiness of adolescents/caregivers is the sum of the 5 aspects that have been described in the readiness assessment framework: cognitive, affective, psychometrics, spiritual-experiential, and social. From these five aspects, there are at least three aspects that must be owned by adolescents/caregivers. However, the combination between the two must still be 8 . That is when the level of readiness of adolescents is at level 3 , but the readiness of caregivers at level 5 , this condition can be disclosed due to a combination of both, namely 8 . Likewise, the opposite. When the caregiver's level of readiness is at level 3, but the readiness of children at level 5 , this pattern can be disclosed. Another pattern that may be carried out disclosure status is the level of readiness of teenagers and caregivers both at level 4 . If the combination of adolescent readiness and caregiver is 
more than 8 , it is strongly recommended to disclose status because both are in ideal conditions.

\section{Conclusion}

This study indicates that although disclosure status in adolescents with HIV must be done immediately, it cannot be done without meticulous and comprehensive preparation process. The process of disclosure status must be carried out by the closest person and when all parties (adolescents with HIV and caregivers) are in a ready state. To find out the extent of this readiness, readiness assessment must be carried out. An accurate and fast way to do that is through psychological tests such as IQ to measure the level of cognitive readiness, and so on. However, if it is difficult, the readiness assessment can use the readiness assessment framework that has been developed in this study. From this study, it can be concluded that to carry out disclosure status, the level of readiness of adolescents and caregivers is at least in number 8 . If less than that, efforts must be made to substantially prepare those mentioned five aspects.

\section{Recomendation}

This study focuses on the pattern of readiness related to disclosed status, but it is not yet developed on how to prepare it in more comprehensive manner. Therefore, further research needs to be conducted more deeply on how to make adolescents and caregivers ready for all aspects. Another recommendation is that caregivers and medical staff need to understand these patterns before conducting disclosure status for adolescents.

\section{Acknowledgements}

This research is funded by the Grant of Indexed International Publication for Final Project of Students/Publikasi Terindeks Internasional Untuk Tugas Akhir Mahasiswa (PITTA) Universitas Indonesia 2017 with contract number 514/UN2.R3.1/HKP.05.00/2017

\section{References}

1. T. Muhaimin, Med. J. of Indonesia 19, 280 (2010)

2. UNICEF, Kerangka Kerja untuk Perlindungan, Perawatan, dan Bantuan Bagi Anak Yatim dan Anak-Anak yang Rentan yang Hidup di Dunia HIV dan AIDS (2004)

3. R. Mutwa, B. Asiimwee-Kateera, E. Kestelyn, J. Vyankandondera, R. Pool, \& R. Boer. PLOS One 8, (2013)

4. J.W. Santrock, Adolescence. Perkembangan Remaja (Erlangga, 2003)

5. W. Bikaako-Kajura, E.Luyirika, D. Purcell, J. Downing, F. Kaharuza, J. Mermin, R. Bunnel, AIDS Behav. 10, 85 (2006)

6. W.L. Neuman, Social Research Methods Qualitative and Quantitative Approaches (Allyn and Bacon, 2006)

7. T.E. Stringer, Action Research (Sage Publication, 2007) 